\title{
Chemical Composition and in Vitro Evaluation of the Antioxidant and Antimicrobial Activities of Eucalyptus gillii Essential Oil and Extracts
}

\section{Dorsaf Ben Hassine ${ }^{1,2}$, Manef Abderrabba ${ }^{2, *}$, Yan Yvon ${ }^{1}$, Ahmed Lebrihi ${ }^{3}$, Florence Mathieu ${ }^{3}$, François Couderc ${ }^{1}$ and Jalloul Bouajila ${ }^{1, *}$}

1 Laboratoire des IMRCP UMR CNRS-5623, Université Paul-Sabatier, 118 route de Narbonne, Toulouse F-31062, France

2 Laboratoire de Physicochimie des Matériaux, IPEST, La Marsa 2070, Tunisia

3 LGC UMR 5503 (CNRS/INPT/UPS), 1 Avenue de l'Agrobiopole, Castanet-Tolosan 31326, France

* Authors to whom correspondence should be addressed; E-Mails: manef@ecopark.rnrt.tn (M.A.); bouajila@cict.fr (J.B.); Tel.: +216-9864-3010 (M.A.); Fax: +216-7146-1518 (M.A.);

Tel.: +33-56-225-6825 (J.B.); Fax: +33-56-225-6826 (J.B.).

Received: 28 June 2012; in revised form: 25 July 2012 / Accepted: 26 July 2012 /

Published: 9 August 2012

\begin{abstract}
In this study, essential oil and various extracts (hexane, petroleum ether, acetone, ethanol, methanol and water) of Eucalyptus gilii were screened for their chemical composition, antimicrobial and antioxidant activities. The essential oil chemical composition was analyzed by gas chromatography-mass spectrometry (GC-MS) and gas chromatography-flame ionization detection (GC-FID), respectively. Thirty four compounds were identified, corresponding to $99.5 \%$ of the total essential oil. Tannins [104.9-251.3 g catechin equivalent $(\mathrm{CE}) / \mathrm{Kg}$ dry mass], flavonoids [3.3-34.3 g quercetin equivalent (QE)/Kg dry mass], phenolics [4.7-216.6 g gallic acid equivalent (GAE)/Kg dry mass] and anthocyannins [1.2-45.3 mg cyanidin-3-glucoside equivalent (C3GE)/Kg dry mass] of various extracts were investigated. Free radical scavenging capacity of all samples was determinedt. In the 1,1-diphenyl-2-picrylhydrazyl (DPPH) assay, the $\mathrm{IC}_{50}$ of essential oil was $163.5 \pm 10.7 \mathrm{mg} / \mathrm{L}$ and in the 2,2'-azinobis-3-ethylbenzothiazoline-6-sulphonate (ABTS) assay, it was $94.7 \pm 7.1 \mathrm{mg} / \mathrm{L}$. Among the various extracts, the water extract showed the best result $\left(\mathrm{IC}_{50}=11.4 \pm 0.6 \mathrm{mg} / \mathrm{L}\right)$ in the DPPH assay which was comparable to vitamin $\mathrm{C}\left(\mathrm{IC}_{50}=4.4 \pm 0.2 \mathrm{mg} / \mathrm{L}\right)$. The antimicrobial activities were evaluated against different bacterial and fungal strains. Gram positive bacteria were found to be more sensitive to the essential oil and extracts than Gram negative ones. Anthocyanins seem to
\end{abstract}


have a major effect on the growth of Bacillus subtilis $\left(\mathrm{R}^{2}=0.79\right)$. A significant antifungal activity was observed against the yeast and fungi. Correlations between chemical composition and antioxidant activities were studied and $\mathrm{R}^{2}$ values were about 0.96 for the effect of phenolics on the DPPH assay.

Keywords: Eucalyptus gillii; essential oil; extracts; GC-MS; antioxidants activity; DPPH; ABTS; antimicrobial activity

\section{Introduction}

In all regions of the World, history shows that medicinal plants have always held an important place. These plants contain essential oils and other substances that can be used in foods (aromas), perfumery (aromatic molecules), aromatherapy, herbal medicines (active) or cosmetics (substances treating skin and hair). Only few hundred, among the countless aromatic species identified in Nature, are used on a commercial scale, so a significant number of these plant resources remain untapped. It has been shown that essential oils obtained from different species of plants are responsible for the antimicrobial effects of spices and herbs that are used to increase the shelf life of foods [1].

Essential oils, currently used as food flavorings, could therefore serve as food preservatives, especially since they are mostly classified Generally Recognized As Safe (GRAS) or approved as food additives by the U.S. Food and Drug Administration [2]. Essential oils have broad spectrum of activity against different bacterial and fungal strains [3]. Furthermore, their antimicrobial activity is mainly based on their chemical composition, in particular the nature of their main volatile components [3-6]. These medicinal plants are distributed worldwide, for example in Tunisia, where the climatic conditions are favorable for wild, cultivated and introduced plants. The value of these natural resources can have significant economic benefits for the country.

Eucalyptus is a native Australian tree. It is represented by more than 900 species [7]. It has been introduced worldwide, including in Tunisia. Eucalyptus is mainly cultivated for its timber, pulp and essential oils that present medicinal properties and therapeutic uses. It is considered an important source of essential oils used in traditional medicine. Eucalyptus essential oil is used to relieve head colds, rheumatism, muscular pain, and as an expectorant in cases of bronchitis [8].

Our interest has focused on one (not studied) species of the genus Eucalyptus which can serve as raw material for extraction of essential oils and various extracts. Our choice is based on the virtues of this plant. To our knowledge no study has been undertaken on leaf extracts of E. gillii. In the present work, we analyzed qualitatively and quantitatively the constituents of E. gillii leaves essential oil and various extracts. Antimicrobial and antioxidant activities of the volatile fraction and various extracts from E. gillii were also investigated. Correlations between chemical composition and biological activities were studied. 


\section{Results and Discussion}

\subsection{Chemical Composition}

\subsubsection{Essential Oil}

The yield of $E$. gillii leaves essential oil was $2.3 \%$ (w/w relative to dry material weight) with a pale yellow color and a persistent odor. Comparing our result to those obtained by Jaimand et al. [9], the yield of this species cultivated in Iran was about 2.4\%. Although the differences in geographic, climatic and ecologic parameters, no significant variability in essential oil content was observed.

The components of E. gillii essential oil have been determined by GC-FID and GC-MS analysis. Thirty-four compounds were identified (Table 1), corresponding to $99.5 \%$ of the total essential oil. The major components were 1,8-cineole (43.8\%), $p$-cymene (14.2\%) and $\alpha$-pinene (10\%). 1,8-Cineole was abundant in all species and these results are in good agreement with those reported by Giamakis et al. [10]; (Eucalyptus essential oil is in the range 20\%-90\%).

Table 1. Chemical composition of essential oil from E. gillii leaves.

\begin{tabular}{|c|c|c|c|}
\hline $\mathbf{N}^{\circ}$ & RI & Compounds & $\%$ Area \\
\hline 1 & 936 & $\alpha$-pinene & 10.0 \\
\hline 2 & 951 & $\alpha$-fenchene & 0.2 \\
\hline 3 & 1025 & $p$-cymene & 14.2 \\
\hline 4 & 1028 & limonene & 1.4 \\
\hline 5 & 1030 & 1,8-cineole & 43.8 \\
\hline 6 & 1033 & $\beta$-phellandrene & 0.1 \\
\hline 7 & 1057 & $\gamma$-terpinene & 0.2 \\
\hline 8 & 1086 & $\alpha$-terpinolene & 0.2 \\
\hline 9 & 1105 & fenchol & 0.1 \\
\hline 10 & 1138 & trans-2-caren-4-ol * & 0.1 \\
\hline 11 & 1140 & cis-sabinol & 5.2 \\
\hline 12 & 1145 & trans-verbenol & 0.1 \\
\hline 13 & 1166 & borneol & 0.3 \\
\hline 14 & 1168 & pinocarvone & 2.6 \\
\hline 15 & 1195 & myrtenal & 0.2 \\
\hline 16 & 1202 & myrtenol & 0.2 \\
\hline 17 & 1208 & verbenone & 0.5 \\
\hline 18 & 1237 & pulegone & 0.1 \\
\hline 19 & 1237 & cuminaldehyde & 0.2 \\
\hline 20 & 1280 & piperitone & 0.3 \\
\hline 21 & 1288 & $p$-cymen-7-ol & 0.1 \\
\hline 22 & 1388 & $\beta$-bourbonene & 0.5 \\
\hline 23 & 1516 & $\alpha$-selinene & 3.1 \\
\hline 24 & 1527 & calamenene & 0.1 \\
\hline 25 & 1560 & germacrene B & 1.1 \\
\hline 26 & 1576 & spathulenol & 4.1 \\
\hline 27 & 1578 & globulol & 0.4 \\
\hline 28 & 1590 & viridiflorol & 0.5 \\
\hline
\end{tabular}


Table 1. Cont.

\begin{tabular}{|c|c|c|c|}
\hline $\mathbf{N}^{\circ}$ & RI & Compounds & $\%$ Area \\
\hline 29 & 1596 & guaiol & 1.0 \\
\hline 30 & 1648 & $\gamma$-eudesmol & 3.6 \\
\hline 31 & 1650 & $\alpha$-cadinol & 1.2 \\
\hline 32 & 1651 & $\beta$-eudesmol & 3.2 \\
\hline 33 & 1805 & nootkatone $*$ & 0.2 \\
\hline \multirow[t]{7}{*}{34} & nd & dihydroumbellulone & 0.1 \\
\hline & & Total & 99.5 \\
\hline & & Monoterpene hydrocarbons & 12.2 \\
\hline & & Oxygenated monoterpenes & 53.6 \\
\hline & & Sesquiterpenes hydrocarbons & 4.9 \\
\hline & & Oxygenated sesquiterpenes & 14.2 \\
\hline & & Others & 14.7 \\
\hline
\end{tabular}

*: Tentative identification supported by good match of MS spectra; nd: Not determined; RI: retention index.

The essential oil consists of oxygenated monoterpenes (53.6\%), oxygenated sesquiterpenes (14.2\%), monoterpene hydrocarbons (12.2\%), sesquiterpene hydrocarbons $(4.9 \%)$ and other components $(14.7 \%)$. No data was reported in the literature regarding the chemical composition of E. gillii essential oil, but we compared it to other species growing in the same region. For example, Naceur et al. [11] indicates that the major components of E. oleosa leaves essential oil were $\alpha$-pinene $12.3 \%$, limonene $12.1 \%$ and 1,8-cineole $26.1 \%$. Comparatively, E. gillii essential oil from central Tunisia presents a higher amount of 1,8-cineole $43.8 \%$ and a lower amount of limonene $1.4 \%$, whereas the amount of $\alpha$-pinene seems to be the same $10 \%$. This result represents the major finding of our study. The qualitative and quantitative analysis showed variability in the essential oil extracted from E. gillii leaves. The chemical composition of essential oil is affected by several factors such as species, geographical location, harvest time, plant part used and isolation method. This variety is different from other Eucalyptus in terms of chemical composition of essential oils, which makes the work interesting.

\subsubsection{Various Extracts}

Extraction yields of various E. gillii extracts are presented in Table 2. Hexane extract has the highest yield (30.7\%), followed by ethanolic extract $(9.0 \%)$, methanolic extract $(6.4 \%)$, then water extract (5.3\%) and acetone extract (5.2\%). Petroleum ether extract presented only $0.3 \%$ yield.

No data relative to our plant has been found in the literature. Amakurra et al. [12] used commercial Eucalyptus leaves from the Japan Food Additive Association, and the yield of $n$-hexane extract was $6.3 \%$, however the hexane extract of E. gillii leaves is about $30.7 \%$. According to the authors, the Eucalyptus product $(50 \mathrm{~g})$ was successively extracted with $n$-hexane $(50 \mathrm{~mL}$, four times), ethyl acetate (50 mL, four times) and $n$-butanol $(50 \mathrm{~mL}$, four times). Manwhile, Li et al. [13] indicate that the hexane yields of Tasmanian E. globulus leaves ranged from 0.2 to $1.5 \%$ dry weight. The yield of E. gillii acetone leaves extract (5.2\%) is more important than the El globulus acetone leaves extract $(0.2 \%)$ obtained by Rahman et al. [14]. We noticed that the yield of E. globulus hot water leaves 
extract is about $13.58 \%$ for Japanese species, obtained by Hasegawa et al. [15]; however, for our E. gillii cold water leaves extract, the yield is about $5.3 \%$.

Table 2. Extraction yields (\%) of essential oil and various extracts of E. gillii.

\begin{tabular}{lc}
\hline Samples & Yield (\%) \\
\hline Essential oil & $2.3 \pm 0.1^{\mathrm{a}}$ \\
Hexane & $30.7 \pm 0.3^{\mathrm{b}}$ \\
Petroleum ether & $0.3 \pm 0.0^{\mathrm{c}}$ \\
Acetone & $5.2 \pm 0.0^{\mathrm{d}}$ \\
Ethanol & $9.0 \pm 0.2^{\mathrm{e}}$ \\
Methanol & $6.4 \pm 0.0^{\mathrm{d}}$ \\
Water & $5.3 \pm 0.0^{\mathrm{d}}$ \\
\hline
\end{tabular}

Values within rows with different superscripts $(\mathrm{a}-\mathrm{e})$ were significantly different $(p<0.05)$; \pm : Standard deviation.

The chemical composition of the various E. gillii extracts is summarized in Table 3. For phenolics, water extract was the most rich (216.6 GAE g/Kg dry mass), followed by ethanol extract (143.4 GAE g/Kg dry mass), methanol extract (143.2 GAE g/Kg dry mass), acetone (53.7 GAE g/Kg dry mass) and finally petroleum ether extract (4.5 GAE g/Kg dry mass). No phenolics were found in the hexane extract.

Table 3. Chemical composition of E. gillii extracts.

\begin{tabular}{lcccc}
\hline Extracts & $\begin{array}{c}\text { Phenolics } \\
(\mathbf{G A E})^{\mathrm{a}}\end{array}$ & $\begin{array}{c}\text { Tannins } \\
(\mathbf{C E})^{\mathrm{a}}\end{array}$ & $\begin{array}{c}\text { Flavonoids } \\
(\mathbf{Q E})^{\mathrm{a}}\end{array}$ & $\begin{array}{c}\text { Anthocyanins } \\
(\mathbf{C 3 G E})^{\mathbf{b}}\end{array}$ \\
\hline Hexane & $\mathrm{nd}^{\mathrm{a}}$ & $152.2 \pm 1.4^{\mathrm{a}}$ & $4.0 \pm 0.1^{\mathrm{a}}$ & $45.3 \pm 0.1^{\mathrm{a}}$ \\
Petroleum ether & $4.5 \pm 0.0^{\mathrm{b}}$ & $133.5 \pm 0.8^{\mathrm{b}}$ & $3.3 \pm 0.1^{\mathrm{b}}$ & $43.4 \pm 0.2^{\mathrm{a}}$ \\
Acetone & $53.7 \pm 0.1^{\mathrm{c}}$ & $104.9 \pm 1.4^{\mathrm{c}}$ & $27.6 \pm 0.4^{\mathrm{c}}$ & $4.7 \pm 0.2^{\mathrm{b}}$ \\
Ethanol & $143.4 \pm 0.1^{\mathrm{d}}$ & $148.6 \pm 1.6^{\mathrm{a}}$ & $34.3 \pm 0.1^{\mathrm{d}}$ & $\mathrm{nd}^{\mathrm{c}}$ \\
Methanol & $143.2 \pm 0.7^{\mathrm{d}}$ & $251.3 \pm 0.7^{\mathrm{d}}$ & $23.9 \pm 0.3^{\mathrm{e}}$ & $1.3 \pm 0.0^{\mathrm{d}}$ \\
Water & $216.6 \pm 0.4^{\mathrm{e}}$ & $231.7 \pm 0.8^{\mathrm{e}}$ & $14.4 \pm 0.2^{\mathrm{f}}$ & $1.2 \pm 0.0^{\mathrm{d}}$ \\
\hline
\end{tabular}

${ }^{\mathrm{a}}: \mathrm{g} / \mathrm{Kg}$ dry mass; ${ }^{\mathrm{b}}: \mathrm{mg} / \mathrm{Kg}$ dry mass; nd: not detected; Values within columns with different superscripts $(\mathrm{a}-\mathrm{f})$ were significantly different $(p<0.05)$; \pm : Standard deviation.

The amount of total tannins varied in the different extracts from $104.9 \pm 0.7$ to $251.3 \pm 1.4$ Catechin Equivalent $\mathrm{g} / \mathrm{Kg}$ dry mass. The highest amount of tannins was found in the methanolic extract $(251.3 \pm 0.7 \mathrm{CE} \mathrm{g} / \mathrm{Kg}$ dry mass), followed by the water extract $(231.7 \pm 0.8 \mathrm{CE} \mathrm{g} / \mathrm{Kg}$ dry mass), then hexane extract $(153.2 \pm 1.4 \mathrm{CE} \mathrm{g/Kg}$ dry mass), ethanol extract $(148.6 \pm 1.6 \mathrm{CE} \mathrm{g/Kg}$ dry mass $)$ and finally acetonic extract (104.9 $\pm 1.4 \mathrm{CE} \mathrm{g} / \mathrm{Kg}$ dry mass).

Flavonoids (3.3-34.3 QE g/Kg dry mass) were also detected in the extracts, the ethanol one (34.3 QE g/Kg dry mass) being the most rich, followed by acetone (27.6 QE g/Kg dry mass) and methanol (23.9 QE g/Kg dry mass). Flavonoids were presented in small amounts compared to the two families mentioned above (phenolics and tannins). 
Anthocyanins were also found, but in small quantity compared to the other families, with an average concentration of $\mathrm{mg} / \mathrm{Kg}$. Hexane extract (45.3 C3GE $\mathrm{mg} / \mathrm{Kg}$ dry mass) and petroleum ether extract (43.4 $\mathrm{C} 3 \mathrm{GE} \mathrm{mg} / \mathrm{Kg}$ dry mass) were the richest in anthocyanins.

Variation in the yields of various extracts was attributed to the apolarity of different compounds in the leaves. Such differences have been reported in literature concerning berries of $J$. phoenicea [16]. We didn't find any data concerning E. gillii extracts.

A comparison with the literature showed that the total phenolics was $11.9 \mathrm{mg} / \mathrm{g}$ gallic acid equivalents from the commercial Eucalyptus leaf extract from the Japan Food Additive Association [12]. It was also cited by Chapuis-Lardy et al. [17], that the amount of total phenolics extracted with methanolic solutions from three Eucalyptus spp. ranged from 116 to $138 \mathrm{mg}$ Tannin Acid Equivalents (TAE)/g dry matter. Distilled water extracts contained 101 to $126 \mathrm{mg}$ TAE/g dry matter. Our Eucalyptus extracts contained more phenolics than those reported in the literature.

The chemical composition of various Eucalyptus leaves extracts showed that this species is very rich in phenolics, which are responsible for the antioxidant activity and other beneficial properties of Eucalyptus leaves extracts. Phenolic compounds were identified from various Eucalyptus leaves, but no such data refers to E. gillii leaves. These compounds vary from some species to others, however, the majority of the ones found were not evaluated for their antioxidant activity. That's why the investigation of these compounds will be of interest to identify any specific molecules which may be responsible for the observed biological activities.

\subsection{Antioxidant Activity}

Essential oil and different extracts were individually assessed for antioxidant activity using two tests: ABTS and DPPH free radical scavenging. Results are summarized in Figure 1.

\subsubsection{Essential Oil}

The antioxidant activity of $E$. gillii essential oil was more important according to the ABTS assay, with an $\mathrm{IC}_{50}$ value of $94.7 \pm 7.1 \mathrm{mg} / \mathrm{L}$ compared to the $\mathrm{DPPH}$ assay with an $\mathrm{IC}_{50}$ of $163.5 \pm 10.7 \mathrm{mg} / \mathrm{L}$ (Figure 1). This activity is significant, especially since this essential oil are composed mainly of monoterpenes and sesquiterpene hydrocarbons and oxygenated ones which have a moderate activity compared to phenolics and vitamin C. Our findings revealed that the percentage of oxygenated monoterpenes was $53.6 \%$ and monoterpenes hydrocarbons was $12.2 \%$. This result might be related to the antioxidant activity of our essential oil.

No antioxidant activity of $E$. gillii essential oil has been previously reported. According to literature, essential oils of Eucalyptus species native to south Tunisia (E. gracilis, E. oleosa, E. salubris, E. salmonophloia) seem to possess lower antioxidant properties than those of central Tunisia (E. gillii). In fact, Naceur et al. [11] have found that $\mathrm{IC}_{50}$ value of all essential oils were in the range 12.0-52.8 g/L, however, E. gillii essential oil showed an $\mathrm{IC}_{50}$ value $163.5 \pm 10.7 \mathrm{mg} / \mathrm{L}$ according to our DPPH assay. The ABTS activity obtained for E. gilii essential oil $\left(\mathrm{IC}_{50}\right.$ value of $\left.94.7 \pm 7.1 \mathrm{mg} / \mathrm{L}\right)$ was also more powerful than those described by Naceur et al. [11] for E. salubris $\left(\mathrm{IC}_{50}\right.$ value of $273.2 \pm 4.1 \mathrm{mg} / \mathrm{mL})$. 
Figure 1. Free radical scavenging capacity $\left[\mathrm{IC}_{50}(\mathrm{mg} / \mathrm{L})\right]$ of essential oil and E. gillii extracts. Petroleum ether extract: not analyzed by ABTS assay. Different letters $(\mathrm{a}-\mathrm{f})$ on the tops of the square columns were significantly different $(p<0.05)$.

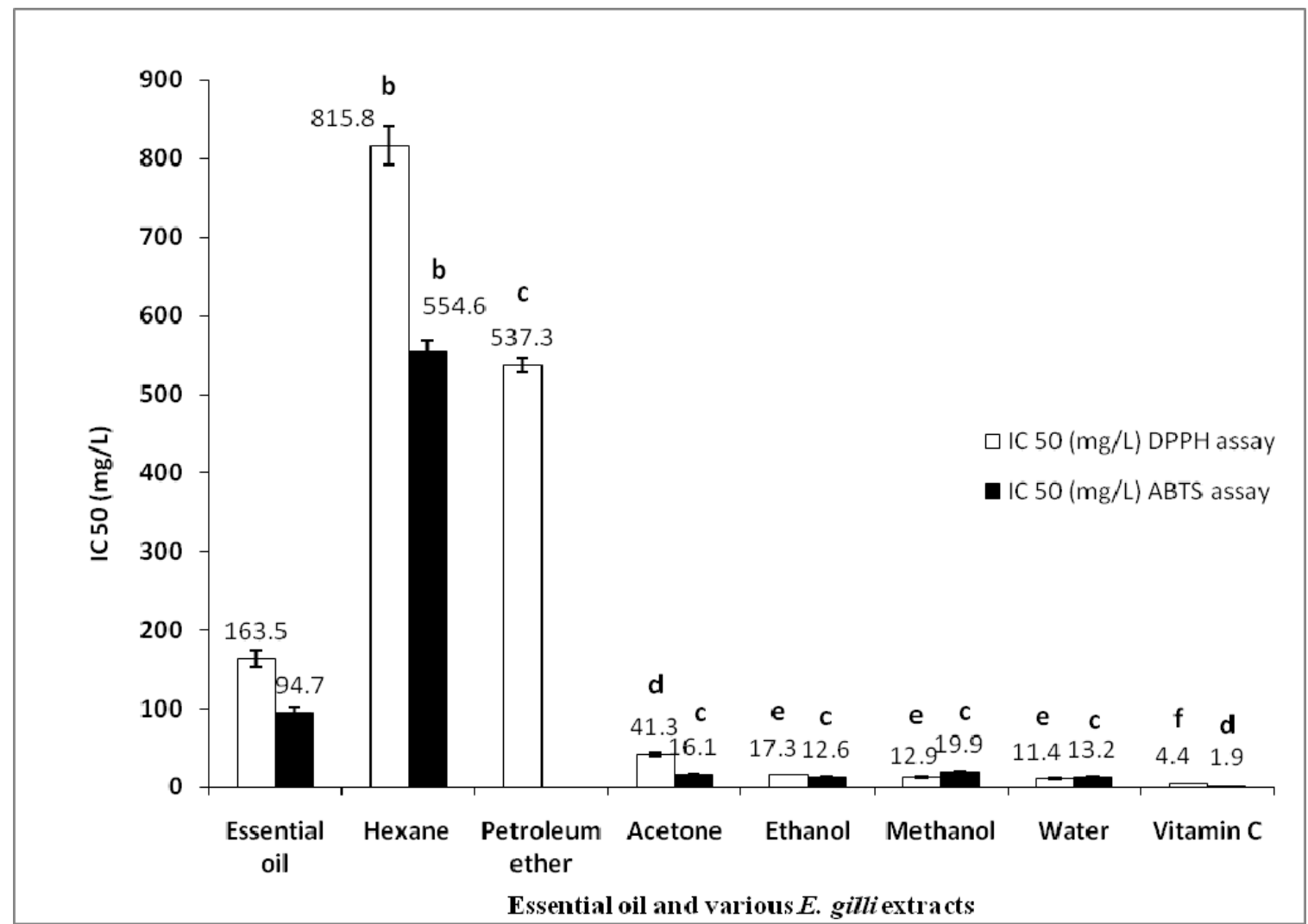

Our results showed that E. gillii essential oil had a very good antioxidant activity compared to E. radiata [18] with a little antioxidant activity found in the ABTS assay $\left(\mathrm{IC}_{50}=484.3 \pm 17.3 \mathrm{mg} / \mathrm{L}\right)$. As cited by Naceur et al. [19] the different parts of E. oleosa showed a small antioxidant activity $\left(\mathrm{IC}_{50}=1,536.3 \pm 40.5 \mathrm{mg} / \mathrm{L}\right)$ when using the DPPH test, and around $13 \pm 0.6 \mathrm{mg} / \mathrm{L}$ when using the ABTS test.

\subsubsection{Various Extracts}

For the DPPH assay (Figure 1), the water extract possessed the most important activity $\left(\mathrm{IC}_{50}=11.4 \pm 0.6 \mathrm{mg} / \mathrm{L}\right)$, followed by the methanol $\left(\mathrm{IC}_{50}=12.9 \pm 0.4 \mathrm{mg} / \mathrm{L}\right)$, ethanol $\left(\mathrm{IC}_{50}=17.3 \pm 0.4 \mathrm{mg} / \mathrm{L}\right)$, acetone $\left(\mathrm{IC}_{50}=41.3 \pm 2.1 \mathrm{mg} / \mathrm{L}\right)$, petroleum ether $\left(\mathrm{IC}_{50}=537.3 \pm 8.7 \mathrm{mg} / \mathrm{L}\right)$ and hexane $\left(\mathrm{IC}_{50}=815.8 \pm 24.8 \mathrm{mg} / \mathrm{L}\right)$ extracts. Ascorbic acid was used as positive control and exhibited an $\mathrm{IC}_{50}$ equal to $4.4 \pm 0.2 \mathrm{mg} / \mathrm{L}$.

With regards to the ABTS assay, the ethanolic extract presented good antioxidant activity $\left(\mathrm{IC}_{50}=12.6 \pm 0.7 \mathrm{mg} / \mathrm{L}\right)$, followed by the water $\left(\mathrm{IC}_{50}=13.2 \pm 1.2 \mathrm{mg} / \mathrm{L}\right)$, acetone $\left(\mathrm{IC}_{50}=16.1 \pm 0.5 \mathrm{mg} / \mathrm{L}\right)$, methanol $\left(\mathrm{IC}_{50}=19.9 \pm 0.2 \mathrm{mg} / \mathrm{L}\right)$ and hexane extracts $\left(\mathrm{IC}_{50}=554.6 \pm 13.3 \mathrm{mg} / \mathrm{L}\right)$. Ascorbic acid was used as positive control and exhibited an $\mathrm{IC}_{50}$ equal to $1.9 \pm 0.1 \mathrm{mg} / \mathrm{L}$.

Comparing the results of ABTS assay to those of the DPPH one, we can deduce that ABTS assay generally presents more activity. 
According to the results found, the best antioxidant activities correspond to the polar fractions (water, ethanol, methanol). It is important to note that the species E. gillii has not been evaluated for antioxidant capacity. Hasegawa et al. [15] found that the high DPPH radical scavenging activity of phenolics isolated from E. globulus using hot water was about $3.8 \mu \mathrm{M}(1.8 \mathrm{mg} / \mathrm{L})$. The antioxidant activity of the methanol extract of E. camaldulensis using the DPPH assay was about an $\mathrm{IC}_{50}=14.0 \pm 0.2 \mathrm{mg} / \mathrm{L}$. Extract was obtained by the extraction of $50 \mathrm{~g}$ of powdered E. camaldulensis leaves three times with $70 \%$ aqueous acetone as cited by Singab et al. [20]. The best $\mathrm{IC}_{50}$ value of our extracts is $11.4 \pm 0.6 \mathrm{mg} / \mathrm{L}$. This value is encouraging enough to prompt us to try to identify the molecules responsible for this activity.

Correlation between chemical composition of various $E$. gillii extracts and antioxidant activity was carried out for both the ABTS and DPPH assays. The composition of phenolics of various extracts seems to have a notable effect on the values of $\mathrm{IC}_{50}$ by the DPPH assay $\left(\mathrm{R}^{2}=0.96\right)$ and $\mathrm{IC}_{50}$ by the ABTS assay $\left(\mathrm{R}^{2}=0.71\right)$. Flavonoids were found to have also an effect on the variability of $\mathrm{IC}_{50}$ for ABTS assay $\left(R^{2}=0.70\right)$ and DPPH assay $\left(R^{2}=0.63\right)$, respectively. This correlation is not cited too often in the literature.

\subsection{Antimicrobial Activity}

\subsubsection{Minimum Inhibitory Concentration (MIC) of Essential Oil}

The antimicrobial activity of $E$. gillii essential oil was evaluated by the determination of the Minimum Inhibitory Concentration (Table 4), which is the first concentration of added essential oil with which we do not notice visible microbial growth. According to results given in Table 4, we deduced that $E$. gillii essential oil exhibited a great potential against Gram positive bacteria, especially Listeria monocytogenes $(\mathrm{MIC}=0.78 \mathrm{mg} / \mathrm{mL}$ ). Concerning the essential oil activity against Gram negative bacteria, Klebseilla pneumoniae was the most sensitive ( $\mathrm{MIC}=2.34 \mathrm{mg} / \mathrm{mL}$ ). We noticed also an important inhibition against yeast and fungi which was almost similar $(3.12-3.90 \mathrm{mg} / \mathrm{mL})$. To our knowledge, it is the first time that the antimicrobial activity of E. gillii was studied.

Several reports have studied the antimicrobial activity of Eucalyptus essential oils. Among these studies, E. globulus fruit essential oil exerted inhibitory activity against all Gram positive bacteria with MIC values between 0.06 and $1 \mathrm{mg} / \mathrm{mL}$. For the tested Gram negative bacteria, E. globulus fruit essential oil did not show a substantial inhibition against Pseudomonas aeruginosa, K. pneumoniae and Escherchia coli. However it exhibited a moderate activity against yeasts with MIC values of 1-4 $\mathrm{mg} / \mathrm{mL}$. All antibiotic resistant bacteria were susceptible to E. globulus fruit essential oil with MIC values between 0.25 and $1 \mathrm{mg} / \mathrm{mL}$, as cited by Mulyaningsih et al. [21]. It was also indicated that the MIC of Eucalyptus dives leaves essential oil from Austria against Pseudomonas putida was $>0.8 \%$, approximately $8 \mathrm{mg} / \mathrm{L}[6]$.

Other researchers have found that the antimicrobial activity of E. globulus essential oil (from Montenegro) was MIC $=0.9 \mathrm{mg} / \mathrm{mL}$ against $E$. coli and Staphylococcus aureus, $\mathrm{MIC}=0.36 \mathrm{mg} / \mathrm{mL}$ against Candida albicans, MIC $=1.57 \mathrm{mg} / \mathrm{mL}$ against $P$. aeruginosa and $K$. pneumoniae. For $P$. aeruginosa, the MIC was about $3.13 \mathrm{mg} / \mathrm{mL}$ [22]. Comparing our results to these findings, we can deduce that $E$. gillii essential oil exhibited a good antimicrobial activity. 
The relatively high antimicrobial activity was most likely due to the presence of compounds which have antimicrobial properties, particularly, 1,8-cineole which represents $43.8 \%$ of the E. gillii essential oil, and which is known to have relatively strong antimicrobial property against many important pathogens and spoilage organisms including $S$. aureus, E. coli and B. subtilis [23,24]. Compounds such as $p$-cymene, $\alpha$-pinene and $\gamma$-terpinene also have relatively strong antimicrobial activity [25]. E. gillii essential oil was rich in oxygenated monoterpenes and this class comprised different active components which we suppose responsible for the antimicrobial power of our essential oil [26,27].

According to those results, we tried to explain the mechanism of the antimicrobial activity. This activity is related to an important characteristic of essential oil which is the hydrophobicity of their chemical components. This particularity allows them to be close to the lipid cell membrane of bacteria, disturbing the cellular structure and make it permeable; which can be responsible for the leakage of some ions and other metabolites, and eventually responsible for cellular death [27-29].

\subsubsection{Various Extracts}

The antimicrobial activity of the different E. gillii extracts (methanol, ethanol, petroleum ether, acetone, hexane and water) was determined against three Gram positive and four Gram negative bacteria, two yeasts and three fungi. Results from the agar diffusion assay for antimicrobial activity of the various extracts are presented in Table 5. The inhibition zone, measured in millimeters, including the diameter of the disc, was used as the criterion for measuring the antimicrobial activity of E. gillii extracts. The inhibition zone diameters obtained were in the range of 11 to $20 \mathrm{~mm}$. The methanol extract showed the highest activity against all microorganisms.

For Gram positive bacteria, the most sensitive microorganism was B. subtilis, followed by S. aureus, while L. monocytogenes was resistant to the hexane extract. Concerning Gram negative bacteria, Salmonella enterica was the most sensitive, with a $17 \mathrm{~mm}$ inhibition zone obtained with the petroleum ether extract, followed by $K$. pneumoniae, $P$. aeruginosa and E. coli which were more resistant against the various extracts. In the case of yeasts, $S$. cervisiae and $C$. albicans were both sensitive to all extracts, and the largest inhibition zone was $16 \mathrm{~mm}$ obtained with the methanol extract. Finally, for fungi, Aspergillus parasiticus was the most sensitive one, and all extracts exhibited a good activity, while $M$. ramamniarus and Fusarium culmorum were most resistant since we didn't notice any inhibition zone with the acetone and petroleum ether extracts. The water extract didn't exhibit antimicrobial activity against any of the strains. To conclude, the data proved that Gram positive bacteria were the most sensitive tested strains towards the various extracts. The MICs of different extracts have not been calculated because the samples only have moderate activity according to the disc diffusion assay method. 
Table 4. Minimum inhibitory concentration for E. gilii essential oil.

\begin{tabular}{|c|c|c|c|c|c|c|c|c|c|c|c|c|}
\hline \multirow[b]{3}{*}{ Samples } & \multicolumn{12}{|c|}{ Minimum Inhibitory Concentration (mg/mL) } \\
\hline & \multicolumn{3}{|c|}{ Gram positive bacteria } & \multicolumn{4}{|c|}{ Gram negative bacteria } & \multicolumn{2}{|c|}{ Yeast } & \multicolumn{3}{|c|}{ Fungi } \\
\hline & B. subtilis & S. aureus & L. monocytogenes & P. aeruginosa & S. enterica & E. coli & K. pneumoniae & S. cerevisiae & C. albicans & A. parasiticus & M. ramamnianus & F. culmorum \\
\hline Essential oil & $3.90 \pm 0.11^{\mathrm{a}}$ & $3.12 \pm 0.08^{\mathrm{b}}$ & $0.78 \pm 0.02^{\mathrm{c}}$ & $3.90 \pm 0.09^{\mathrm{a}}$ & $3.12 \pm 0.06^{\mathrm{b}}$ & $3.90 \pm 0.14^{\mathrm{a}}$ & $2.34 \pm 0.07^{\mathrm{d}}$ & $3.90 \pm 0.10^{\mathrm{a}}$ & $3.12 \pm 0.08^{b}$ & $3.90 \pm 0.12^{\mathrm{a}}$ & $3.12 \pm 0.10^{\mathrm{b}}$ & $3.12 \pm 0.08^{b}$ \\
\hline Ampicillin & $0.02 \pm 0.00$ & $0.02 \pm 0.00$ & $0.02 \pm 0.00$ & $0.01 \pm 0.00$ & $0.02 \pm 0.00$ & $0.02 \pm 0.00$ & $0.01 \pm 0.00$ & $0.02 \pm 0.00$ & $0.02 \pm 0.00$ & $0.02 \pm 0.00$ & $0.02 \pm 0.00$ & $0.02 \pm 0.00$ \\
\hline Nalidixic acid & $0.02 \pm 0.00$ & $0.02 \pm 0.00$ & $0.02 \pm 0.00$ & $0.01 \pm 0.00$ & $0.02 \pm 0.00$ & $0.02 \pm 0.00$ & $0.01 \pm 0.00$ & $0.08 \pm 0.00$ & $0.02 \pm 0.00$ & $0.02 \pm 0.00$ & $0.02 \pm 0.00$ & $0.02 \pm 0.00$ \\
\hline Nystatin & $0.02 \pm 0.00$ & $0.08 \pm 0.00$ & $0.08 \pm 0.00$ & $0.02 \pm 0.00$ & $0.02 \pm 0.00$ & $0.02 \pm 0.00$ & $0.02 \pm 0.00$ & $0.02 \pm 0.00$ & $0.02 \pm 0.00$ & $0.01 \pm 0.00$ & $0.02 \pm 0.00$ & $0.02 \pm 0.00$ \\
\hline
\end{tabular}

Values within rows with uncommon superscripts (a-d) were significantly different $(p<0.05)$; \pm : Standard deviation.

Table 5. Zone of inhibition of microorganisms by E. gillii extracts.

\begin{tabular}{|c|c|c|c|c|c|c|c|c|c|c|c|c|}
\hline \multirow[b]{3}{*}{ Samples } & \multicolumn{12}{|c|}{ Zones of inhibition $(\mathrm{mm})$} \\
\hline & \multicolumn{3}{|c|}{ Gram positive bacteria } & \multicolumn{4}{|c|}{ Gram negative bacteria } & \multicolumn{2}{|c|}{ Yeast } & \multicolumn{3}{|c|}{ Fungi } \\
\hline & B. subtilis & S. aureus & L. monocytogenes & P. aeruginosa & S. enterica & E. coli & K. pneumoniae & S. cerevisiae & C. albicans & A. parasiticus & M. ramamnianus & F. culmorum \\
\hline Hexane & $14 \pm 0^{\mathrm{a}}$ & $11 \pm 0^{\mathrm{a}}$ & $-{ }^{a}$ & $12 \pm 0^{\mathrm{a}}$ & $13 \pm 0^{\mathrm{a}}$ & $14 \pm 0^{\mathrm{a}}$ & $12 \pm 0^{\mathrm{a}}$ & $12 \pm 0^{\mathrm{a}}$ & $11 \pm 0^{\mathrm{a}}$ & $12 \pm 0^{\mathrm{a}}$ & $12 \pm 0^{\mathrm{a}}$ & $14 \pm 0^{\mathrm{a}}$ \\
\hline Petroleum ether & $13 \pm 0^{\mathrm{a}}$ & $12 \pm 0^{\mathrm{a}}$ & $20 \pm 0^{\mathrm{b}}$ & $13 \pm 0^{\mathrm{a}}$ & $18 \pm 0^{\mathrm{b}}$ & $-{ }^{b}$ & $13 \pm 0^{\mathrm{a}}$ & $11 \pm 0^{\mathrm{a}}$ & $11 \pm 0^{\mathrm{a}}$ & $12 \pm 0^{\mathrm{a}}$ & $-b$ & $12 \pm 0^{\mathrm{a}}$ \\
\hline Acetone & $16 \pm 0^{\mathrm{a}}$ & $13 \pm 0^{\mathrm{a}}$ & $13 \pm 0^{\mathrm{c}}$ & $13 \pm 0^{\mathrm{a}}$ & $14 \pm 0^{\mathrm{a}}$ & $12 \pm 0^{\mathrm{a}}$ & $12 \pm 0^{\mathrm{a}}$ & $14 \pm 0^{\mathrm{a}}$ & $15 \pm 0^{\mathrm{b}}$ & $11 \pm 0^{\mathrm{a}}$ & $-{ }^{b}$ & $-{ }^{b}$ \\
\hline Ethanol & $16 \pm 0^{\mathrm{a}}$ & $18 \pm 0^{\mathrm{b}}$ & $11 \pm 0^{\mathrm{c}}$ & $15 \pm 0^{\mathrm{b}}$ & $15 \pm 0^{\mathrm{a}}$ & $15 \pm 0^{\mathrm{a}}$ & $17 \pm 0^{\mathrm{b}}$ & $15 \pm 0^{\mathrm{b}}$ & $16 \pm 0^{\mathrm{b}}$ & $15 \pm 0^{\mathrm{b}}$ & $14 \pm 0^{\mathrm{a}}$ & $15 \pm 0^{\mathrm{c}}$ \\
\hline Methanol & $20 \pm 1^{b}$ & $15 \pm 0^{\mathrm{c}}$ & $16 \pm 0^{\mathrm{d}}$ & $-{ }^{c}$ & $13 \pm 0^{\mathrm{a}}$ & $17 \pm 0^{\mathrm{c}}$ & $13 \pm 0^{\mathrm{a}}$ & $17 \pm 0^{\mathrm{b}}$ & $13 \pm 0^{\mathrm{a}}$ & $13 \pm 0^{\mathrm{a}}$ & $13 \pm 0^{\mathrm{a}}$ & $16 \pm 0^{\mathrm{c}}$ \\
\hline Water & $--^{c}$ & $-{ }^{d}$ & $-{ }^{a}$ & $-{ }^{c}$ & $-{ }^{c}$ & $-{ }^{b}$ & $--^{c}$ & $-{ }^{c}$ & $-{ }^{c}$ & $-{ }^{c}$ & $-{ }^{b}$ & $-{ }^{b}$ \\
\hline Ampicillin & $54 \pm 2^{c}$ & $20 \pm 0^{\mathrm{b}}$ & $31 \pm 1^{\mathrm{e}}$ & & & & & & & & & \\
\hline Nalidixic acid & & & & $19 \pm 0^{d}$ & $27 \pm 1^{d}$ & $30 \pm 1^{\mathrm{d}}$ & $28 \pm 0^{d}$ & & & & & \\
\hline Nystatin & & & & & & & & $29 \pm 1^{\mathrm{d}}$ & $30 \pm 1^{\mathrm{d}}$ & $24 \pm 0^{\mathrm{d}}$ & $31 \pm 1^{\mathrm{c}}$ & $30 \pm 1^{d}$ \\
\hline
\end{tabular}

“-”: Absence of inhibition zone detected. Extract mass $=0.4 \mathrm{mg} /$ disc. Antibiotic concentration $=0.33 \mathrm{mg} / \mathrm{L}$. Values within columns with uncommon superscripts $(\mathrm{a}-\mathrm{d})$ were significantly different $(p<0.05)$;

\pm : Standard deviation. 
Results prove that all tested extracts are endowed with an antimicrobial activity in spite of the morphological diversity of microorganism strains, concentration and variability of the chemical composition of every applied extract. Correlation between the chemical composition of each family and the antimicrobial activity of each strain were evaluated for the disc diffusion assay. The results show that anthocyanins seem to have a major effect on the growth of $B$. subtilis $\left(\mathrm{R}^{2}=0.79\right)$ : the size of the inhibition zone increases when the amount of anthocyanins also increases.

\section{Experimental}

\subsection{Chemicals}

All chemicals used were of analytical reagent grade. All reagents were purchased from Sigma-Aldrich-Fluka (Saint-Quentin, France).

\subsection{Collection of Plant Material}

E. gillii leaves were picked on April 2009 from trees growing in the Hajeb Layoun arboretum, located in Kairouan governorship in Tunisia. They were stored at a dry place for fifteen days. Specimens were identified at the Regional Station of the National Institute of Research in Farming Studies, Waters and Forests. A voucher specimen (reference 0109) was deposited at the Department of Biology. The arboretum was established in April 1960 and the plant was originally imported from Austria. Dried leaves were subjected to hydrodistillation and preparation of the various extracts.

\subsection{Extraction}

\subsubsection{Isolation of Essential oil}

One hundred $\mathrm{g}$ of dried leaves were crushed (2.5 $\mathrm{mm}$ of diameter), then subjected to hydrodistillation ( $500 \mathrm{~mL}$ water) in a Clevenger type apparatus for $3 \mathrm{~h}$. The essential oil obtained was dried with anhydrous sodium sulfate and kept in amber vials at $4{ }^{\circ} \mathrm{C}$ for further analysis. $\mathrm{Na}_{2} \mathrm{SO}_{4}$ was removed before use of the essential oil. The extraction yield was calculated using the following formula: yield $=\left(\mathrm{V}_{\mathrm{EO}} \times 100\right) / D \cdot M\left(D . M\right.$ : dry material; $\mathrm{V}_{\mathrm{EO}}$ : volume of essential oil $)$.

\subsubsection{Preparation of Extracts}

The extraction method was sequential extraction with solvents of increasing polarity. Solvents used were: hexane, petroleum ether, acetone, ethanol, methanol and water. Ten $g$ of harvested leaves, finely crushed, were placed in hexane $(100 \mathrm{~mL})$ for $16 \mathrm{~h}$ under frequent agitation at ambient pressure and temperature. The mixture was filtered using Wattman paper (GF/A, $110 \mathrm{~mm}$ ). The solvent was evaporated using a rotary evaporator under vacuum at $35^{\circ} \mathrm{C}$. Then, the firstly extracted powder was extracted with petroleum ether under the same conditions as with hexane. The same procedure was applied for the following solvents. Extracts were kept in amber vials and stored at $4{ }^{\circ} \mathrm{C}$ for further analysis. 


\subsection{Gas Chromatography and Gas Chromatography-Mass Spectrometry}

Quantitative and qualitative analysis of the essential oil was carried out by gas chromatography-flame ionization detection (GC-FID) and gas chromatography-mass spectrometry (GC-MS). Gas chromatography analyses were carried out on a Varian Star 3400 (Les Ulis, France) Cx chromatograph fitted with a fused silica capillary DB-5MS column $(5 \%$ phenylmethylpolysiloxane, $30 \mathrm{~m} \times 0.25 \mathrm{~mm}$, film thickness $0.25 \mu \mathrm{m}$ ). Chromatographic conditions were $60{ }^{\circ} \mathrm{C}$ to $260{ }^{\circ} \mathrm{C}$ temperature rise with a gradient of $5{ }^{\circ} \mathrm{C} / \mathrm{min}$ and $15 \mathrm{~min}$ isotherm at $260{ }^{\circ} \mathrm{C}$. A second gradient was applied to $340{ }^{\circ} \mathrm{C}$ at $40^{\circ} \mathrm{C} / \mathrm{min}$. Total analysis time was $57 \mathrm{~min}$.

For analysis, essential oil was dissolved in petroleum ether. One microliter of sample was injected in 1:10 split mode. Helium (purity 99.999\%) was used as carrier gas at $1 \mathrm{~mL} / \mathrm{min}$. The injector was operated at $200{ }^{\circ} \mathrm{C}$. The mass spectrometer (Varian Saturn GC/MS/MS 4D) was adjusted for an emission current of $10 \mu \mathrm{A}$ and electron multiplier voltage between 1,400 and 1,500 V. Trap temperature was $220{ }^{\circ} \mathrm{C}$ and that of the transfer line was $250{ }^{\circ} \mathrm{C}$. Mass scanning was from 40 to $650 \mathrm{amu}$.

Compounds were identified by comparison of their KI (retention indices) relative to $\mathrm{C}_{5}-\mathrm{C}_{24}$ $n$-alkanes obtained on a nonpolar DB-5MS column, with those provided in the literature, by comparison of their mass spectra with those recorded in NIST 08 (National Institute of Standards and Technology) and reported in published articles and by co-injection of available reference compounds [ $\alpha$-pinene (98\%, Aldrich); $p$-cymene (99\%, Aldrich); limonene ( $\geq 99.0 \%$, Fluka); 1,8-cineole (99\%, Aldrich); $\gamma$-terpinene (97\%, Aldrich); $\alpha$-terpinolene ( $\geq 95.0 \%$, Aldrich); fenchol ( $\geq 99.0 \%$, Fluka); borneol (97\%, Aldrich); myrtenal (98\%, Aldrich); myrtenol ( $\geq 95.0 \%$, Aldrich); verbenone (94\%, Aldrich); pulegone ( $\geq 98.5 \%$, Fluka); cuminaldehyde (98\%, Aldrich); p-cymen-7-ol (97\%, Aldrich); globulol ( $\geq 98.5 \%$, Aldrich); guaiol (97\%, Aldrich); $\beta$-eudesmol ( $>90 \%$, Sigma)]. The samples were analyzed in duplicate. The percentage composition of the essential oil was computed by the normalization method from the GC peak areas, assuming identical mass response factor for all compounds. Results were calculated as mean values of three injections from essential oil, without using correction factors. All determinations were performed in triplicate and averaged.

\subsection{Free Radical Scavenging Activity: DPPH Test}

Antioxidant scavenging activity was studied using 1,1-diphenyl-2-picrylhydrazyl free radical (DPPH) as described by Blois [30] with some modifications. Various dilutions of samples (extracts or essential oil, $1.5 \mathrm{~mL}$ ) were mixed with $0.2 \mathrm{mM}$ methanolic DPPH solution $(1.5 \mathrm{~mL})$. After an incubation period of $30 \mathrm{~min}$ at $25{ }^{\circ} \mathrm{C}$, the absorbance at $520 \mathrm{~nm}$ was measured. The wavelength of

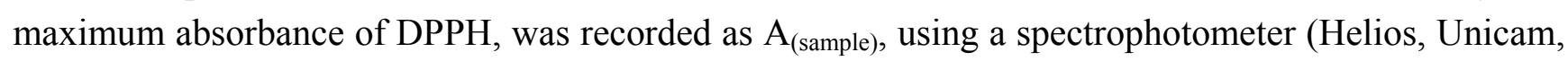
Cambridge, UK). A blank experiment was also carried out applying the same procedure to a solution without the test material and the absorbance was recorded as $\mathrm{A}_{\text {(blank). }}$ The free radical-scavenging activity of each solution was then calculated as percent inhibition according to the following equation:

$\%$ inhibition $=\left(\left(\mathrm{A}_{(\text {blank })}-\mathrm{A}_{(\text {sample })}\right) / \mathrm{A}_{(\text {blank })}\right) \times 100$. 
Antioxidant activity of standard or samples was expressed as $\mathrm{IC}_{50}$, defined as the concentration of the test material required to cause a 50\% decrease in initial DPPH concentration. Ascorbic acid was used as a standard. All measurements were performed in triplicate.

\subsection{ABTS Radical-Scavenging Assay}

The radical scavenging capacity of antioxidants for the ABTS (2,2'-azinobis-3-ethylbenzothiazoline6-sulphonate) radical cation was determined as follows: ABTS was generated by mixing a $7 \mathrm{mM}$ solution of ABTS at pH $7.4\left(5 \mathrm{mM} \mathrm{NaH}_{2} \mathrm{PO}_{4}, 5 \mathrm{mM} \mathrm{Na}_{2} \mathrm{HPO}_{4}\right.$ and $\left.154 \mathrm{mM} \mathrm{NaCl}\right)$ with $2.5 \mathrm{mM}$ potassium persulfate (final concentration) followed by storage in the dark at room temperature for $16 \mathrm{~h}$ before use. The mixture was diluted with persulfate buffer to give an absorbance of $0.70 \pm 0.02$ units at $734 \mathrm{~nm}$ using a spectrophotometer (Helios, Unicam, Cambridge, UK). For each sample, diluted solution of the essential oil $(100 \mu \mathrm{L})$ was allowed to react with fresh ABTS solution $(900 \mu \mathrm{L})$, and then the absorbance was measured 6 min after initial mixing. Ascorbic acid was used as a standard. The capacity of free radical scavenging was expressed by $\mathrm{IC}_{50}(\mathrm{mg} / \mathrm{L})$ values which represents the concentration required to scavenge $50 \%$ of ABTS radicals. The capacity of free radical scavenging $\mathrm{IC}_{50}$ was determined using the same equation previously used for the DPPH method. All measurements were performed in triplicate.

\subsection{Total Amount of Phenolic Compounds}

The total phenolics of each extract were determined by the Folin-Ciocalteu [31] method. Preparation of $2 \mathrm{~N}$ Folin and Ciocalteu reagent (Fluka): dissolve sodium tungstate (10 g) and sodium molybdate $(2.5 \mathrm{~g})$ in water $(70 \mathrm{~mL})$. Add $85 \%$ phosphoric acid $(5 \mathrm{~mL})$ and concentrated hydrochloric acid $(10 \mathrm{~mL})$. Reflux for $10 \mathrm{~h}$. Add lithium sulfate $(15 \mathrm{~g})$, water $(5 \mathrm{~mL})$, and 1 drop of bromine. Reflux for $15 \mathrm{~min}$. Cool to room temperature and bring to $100 \mathrm{~mL}$ with water. Hexavalent phosphomolybdic/ phosphotungstic acid complexes are formed in solution.

The diluted aqueous solution of each extract $(0.1 \mathrm{~mL})$ was mixed with Folin-Ciocalteu reagent $(0.5 \mathrm{~mL}$ at $0.2 \mathrm{~N})$. This mixture was allowed to stand at room temperature for $5 \mathrm{~min}$ and then sodium carbonate solution $(0.4 \mathrm{~mL}$ at $75 \mathrm{~g} / \mathrm{L})$ was added. After $1 \mathrm{~h}$ of incubation, the absorbances were measured at $765 \mathrm{~nm}$ against water blank using a Helios spectrophotometer (Unicam, Cambridge, UK). A standard calibration curve was plotted using gallic acid ( 0 to $200 \mathrm{mg} / \mathrm{L}$ ). The results were expressed as $\mathrm{mg}$ of gallic acid equivalents (GAE)/1 $\mathrm{g}$ of dry mass.

\subsection{Condensed Tannin Content}

Catechins and proanthocyanidins reactive to vanillin were analyzed by the vanillin method [32,33]. One milliliter $(0.5 \mathrm{~mL})$ of each extract solution was placed in a test tube and $2 \mathrm{~mL}$ of vanillin $(1 \%$ in $7 \mathrm{M} \mathrm{H}_{2} \mathrm{SO}_{4}$ ) in an ice bath and then incubated at $25^{\circ} \mathrm{C}$. After $15 \mathrm{~min}$, the absorbance of the solution was read at $500 \mathrm{~nm}$. Concentrations were calculated as gram catechin equivalents $(\mathrm{CE}) / \mathrm{kg}$ dry mass from a calibration curve. 


\subsection{Total Flavonoids Determination}

The total flavonoids were estimated according to the Dowd method as adapted by Arvouet-Grand et al. [34]. A diluted methanolic solution $(0.5 \mathrm{~mL})$ of each extract was mixed with a solution $(0.5 \mathrm{~mL})$ of aluminum trichloride $\left(\mathrm{AlCl}_{3}\right)$ in methanol $(2 \%)$. The absorbance was read at $415 \mathrm{~nm}$ after $15 \mathrm{~min}$ against a blank sample consisting of a methanol $(0.5 \mathrm{~mL})$ and extract $(0.5 \mathrm{~mL})$ without $\mathrm{AlCl}_{3}$. Quercetin was used as reference compound to produce the standard curve, and the results were expressed as gram of quercetin equivalents $(\mathrm{QE}) / \mathrm{kg}$ of dry mass.

\subsection{Determination of Total Anthocyanin Content}

Total anthocyanin content was measured with the $\mathrm{pH}$ differential absorbance method, as described by Cheng et al. [35]. Briefly, absorbance of the extract was measured at 510 and $700 \mathrm{~nm}$ in buffers at $\mathrm{pH} 1$ (hydrochloric acid-potassium chloride, $0.2 \mathrm{M}$ ) and 4.5 (acetic acid-sodium acetate, $1 \mathrm{M}$ ). The wavelength reading was performed after $15 \mathrm{~min}$ of incubation. Anthocyanin content was calculated using a molar extinction coefficient $(\varepsilon)$ of 29,600 (cyanidin-3-glucoside) and absorbance of $\mathrm{A}=\left[\left(\mathrm{A}_{510}-\mathrm{A}_{700}\right) \mathrm{pH} 1.0-\left(\mathrm{A}_{510}-\mathrm{A}_{700}\right) \mathrm{pH} 4.5\right]$. Results were expressed as milligram cyanidin-3-glucoside equivalent $(\mathrm{C} 3 \mathrm{GE}) / \mathrm{kg}$ of dry mass.

\subsection{Antimicrobial Activity}

\subsubsection{Microbial Strains}

All strains were obtained from the Laboratory of Chemical Engineering, Bioprocess Systems Microbiens Department, Ecole Nationale Supérieure Agronomique de Toulouse. The essential oil was individually tested against a panel of microorganisms. Seven bacteria including three Gram positive (Staphylococcus aureus CIP 7625, Listeria monocytogenes Scott A 724, Bacillus subtilis ATCC 6633), and four Gram negative (Pseudomonas aeruginosa CIPA22, Salmonella enterica CIP833, Escherchia coli ATCC 10536, Klebseilla pneumoniae CIP 8291) were used. Two yeasts (Saccharomyces cerevisiae EDV 436 and Candida albicans IPA 200) and three fungi (Aspergillus parasiticus NRRL 3174, Mucor ramamnianus NRLL 1829 and Fusarium culmorum NRRL 3288) were also tested. The bacterial and yeast strains were cultured on nutrient agar for $48 \mathrm{~h}$ at $37{ }^{\circ} \mathrm{C}$, while fungi were propagated in PDA (F. culmorum) and in $\operatorname{ISPD}_{2}$ (A. parasiticus, M. ramamnianus) at $30^{\circ} \mathrm{C}$ for $48 \mathrm{~h}$ to 3 days before used. All microorganisms were stocked at $-6{ }^{\circ} \mathrm{C}$ in appropriate conditions and were regenerated twice before use in the manipulations.

Growing stock culture was normalized through various cycles of growth. Indeed, the density varies between bacteria, yeasts and fungi. The bacterial suspensions were prepared from pre-cultures of $24 \mathrm{~h}$ on Trypticase-soy at $37{ }^{\circ} \mathrm{C}$ in sterile distilled water, and adjusted to $4 \times 10^{6}$ bacteria $/ \mathrm{mL}$. Spores of strains fungi are recovered using a swab to surface of a culture of seven days on sabouraud agar and suspended in sterile distilled water containing $0.05 \%$ polysorbate 80 to a better dispersion of spores. After vortex treatment, the spore suspension is adjusted to the desired concentration by cell count in Thomas cells by light microscopy $(\times 400)$. The concentration of spores suspensions (fungi and yeasts) was about $25 \times 10^{5}$ cells per $\mathrm{mL}$. 
The choice of the used concentrations of inoculums size is traduced by the influence of inoculum size on antimicrobial activity. In fact, a bacterial population introduced into a new culture medium has a fairly characteristic change. The concentration of chosen inoculums must be in the exponential phase to ensure an optimal response of microorganisms to various antimicrobial agents.

\subsubsection{MIC Agar Dilution Assay}

The minimum inhibitory concentration (MIC) values of microorganisms were studied, based on the agar dilution method. The essential oils of E. gillii were dissolved with methanol ( $400 \mu \mathrm{L}$ of essential oil in $400 \mu \mathrm{L}$ methanol). The essential oil dissolved was added aseptically to sterile nutrient agar supplemented with Tween $80(0.5 \%)$ at appropriate volume to produce the concentration range of $0.5-20 \mathrm{mg} / \mathrm{mL}$. No antimicrobial activity noticed for methanol.

The resulting nutrient agar solutions were immediately poured into Petri dish after vortexing and allowed to solidify. The dish was left to cool down and to solidify at room temperature for $30 \mathrm{~min}$. The plates were spotted, then inoculated with $1 \mu \mathrm{L}$ of bacterial strains $\left(4 \times 10^{6}\right.$ cells $\left./ \mathrm{mL}\right)$, of yeast and fungi $\left(25 \times 10^{5}\right.$ spores $\left./ \mathrm{mL}\right)$. Tests were carried out in duplicate.

Ampicillin and nalidixic acid $(0.5-20 \mathrm{mg} / \mathrm{L})$ were used as positive reference standards to determine the sensitivity of Gram positive and Gram negative bacterial species tested respectively. Nystatin $(0.5-20 \mathrm{mg} / \mathrm{L})$ was used as a positive reference standard to determine the sensitivity of fungi and yeast species. These plates, after staying at $4{ }^{\circ} \mathrm{C}$ for $2 \mathrm{~h}$, were incubated at $37{ }^{\circ} \mathrm{C}$ for bacteria and at $30{ }^{\circ} \mathrm{C}$ for $48 \mathrm{~h}$ for yeast and fungi. Tests were carried out in duplicate.

\subsubsection{Disc-Diffusion Assay}

The paper disc diffusion method was employed for the determination of antimicrobial activity of various E. gillii extracts [36]. Briefly, a suspension of the tested microorganism $\left(0.1 \mathrm{~mL}\right.$ of $10^{8}$ cells per $\mathrm{mL}$ for bacteria and $25 \times 10^{5}$ cells per $\mathrm{mL}$ for fungi) was spread on nutrient agar. The discs have a diameter $9 \mathrm{~mm}$, and $40 \mu \mathrm{L}$ of the diluted extract in methanol (1/100 from the initial concentration) were injected and placed on the inoculated plates. Ampicillin and nalidixic acid ( $40 \mu \mathrm{g} / \mathrm{disc})$ were used as positive reference standards to determine the sensitivity of Gram positive, Gram negative bacterial species tested, respectively. Nystatin $(40 \mu \mathrm{g} / \mathrm{disc})$ was used as positive reference standard to determine the sensitivity of fungus and yeasts species. No antimicrobial activity was noticed for methanol.

These plates, after staying at $4{ }^{\circ} \mathrm{C}$ for $2 \mathrm{~h}$, were incubated for $48 \mathrm{~h}$ at $37{ }^{\circ} \mathrm{C}$ for bacteria and at $30{ }^{\circ} \mathrm{C}$ for yeasts and fungus. Antimicrobial activity was evaluated by measuring the zone of inhibition against the test organism. The diameter of the inhibition zones were measured in millimeters. Tests were carried out in triplicate.

The sensitivity to the individual extracts was classified by the diameter of the inhibition zones as indicated by Moreira et al. [37] with a small modification. Not sensitive for total diameter smaller than $9 \mathrm{~mm}$; sensitive for total diameter 10-15 mm; Very sensitive for total diameter 16-20 mm; extremely sensitive for total diameter larger than $20 \mathrm{~mm}$. 


\subsection{Statistical Analysis}

All data were expressed as means \pm standard deviations of triplicate measurements. The confidence limits were set at $p<0.05$. Standard deviations (SD) did not exceed $5 \%$ for the majority of the values obtained. Correlation coefficients $\left(\mathrm{R}^{2}\right)$ to determine the relationship between chemical composition and antioxidant or biological activity were calculated.

\section{Conclusions}

Eucalyptus essential oil and its extracts are known for their therapeutic virtue owing to their antimicrobial activity. They may be used in food industry, not only as flavoring agents but also as preservatives [5,38]. In this work, the major constituents of E. gillii leaves essential oil were 1,8-Cineole (43.8\%), p-cymene (14.2\%), $\alpha$-pinene (10\%). High antioxidant activity was detected (ethanol extract, $\mathrm{IC}_{50}=12.6 \pm 0.7 \mathrm{mg} / \mathrm{L}$ ) by the ABTS assay. Further work is in progress to purify the extract that gave a good antioxidant activity to identify the molecule(s) responsible for this activity. The results of antimicrobial activity showed that L. monocytogenes seems to be the most sensitive Gram positive bacteria, (MIC $=0.78 \mathrm{mg} / \mathrm{mL}) ;$ K. pneumonia presents the lowest MIC $(2.34 \mathrm{mg} / \mathrm{mL}$ ) among the other Gram negative bacteria. Yeast and fungi present an approximate MIC of almost 3.12 to $3.9 \mathrm{mg} / \mathrm{mL}$. These research findings lead us to conclude that E. gillii essential oil and various extracts, mainly the methanolic one, could be considered as potential alternatives for synthetic bactericides and natural antioxidants for use in the food industry along with their possible applications in the pharmaceutical industry for the prevention or treatment of pathogenesis caused by microorganisms and free radicals.

\section{Acknowledgments}

We are very grateful to Mohamed Larbi Khouja (INRGREF, B.P10, Ariana Tunisia) for providing us with plant material.

\section{References}

1. Lambert, R.J.W.; Skandamis, P.N.; Coote, P.; Nychas, G.J.E. A study of the minimum inhibitory concentration and mode of action of oregano essential oil, thymol and carvacrol. J. Appl. Microbiol. 2001, 91, 453-462.

2. Guidance for Industry: Frequently Asked Questions about GRAS. Available online: http://www.fda.gov/Food/GuidanceComplianceRegulatoryInformation/GuidanceDocuments/ FoodIngredientsandPackaging/ucm061846.htm/ (accessed on 13 October 2010).

3. Pittman, C.I.; Pendleton, S.; Bisha, B.; O’Bryan, C.A.; Belk, K.E.; Goodridge, L.; Crandall, P.G.; Ricke, S.C. Activity of citrus essential oils against Escherichia coli O157:H7 and Salmonella spp. and effects on beef subprimal cuts under refrigeration. J. Food Sci. 2011, 76, M433-M438.

4. Karabagias, I.; Badeka, A.; Kontominas, M.G. Shelf life extension of lamb meat using thyme or oregano essential oils and modified atmosphere packaging. Meat Sci. 2011, 88, 109-116. 
5. Djenane, D.; Aïder, M.; Yangüela, J.; Idir, L.; Gómez, D.; Roncalés, P. Antioxidant and antibacterial effects of Lavandula and Mentha essential oils in minced beef inoculated with $E$. coli O157:H7 and S. aureus during storage at abuse refrigeration temperature. Meat Sci. 2012, doi:10.1016/j.meatsci.2012.06.019.

6. Oussalah, M.; Caillet, S.; Saucier, L.; Lacroix, M. Antimicrobial effects of selected plant essential oils on the growth of a Pseudomonas putida strain isolated from meat. Meat Sci. 2006, 73, 236-244.

7. Brooke, M.I.H.; Kleinig, D.A. Field Guide to Eucalypts, 2nd Revised ed.; Bloomings Books Pty Ltd.: Burnley, VIC, Australia, 2004.

8. Guimarães, R.; João Sousa, M.; Ferreira, I.C.F.R. Contribution of essential oils and phenolics to the antioxidant properties of aromatic plants. Ind. Crops Prod. 2010, 32, 152-156.

9. Jaimand, K.; Assareh, M.H.; Rezaee, M.B. Volatile oil constituents of leaves of the Eucalyptus gillii maiden and E. microcarpa subsp. macrocarpa Hook from Iran. Iran. J. Pharm. Res. 2006, 1, $73-75$.

10. Giamakis, A.; Kretsi, O.; Chinou, I.; Spyropoulos, C.G. Eucalyptus camaldulensis: Volatiles from immature flowers and high production of 1,8-cineole and $\hat{a}$-pinene by in vitro cultures. Phytochemistry 2001, 58, 351-355.

11. Naceur, H.; Romdhane, M.; Lebrihi, A.; Mathieu, F.; Couderc, F.; Abderraba, M.; Khouja, M.L.; Bouajila, J. Eucalyptus (gracilis, oleosa, salubris, and salmonophloia) essential oils: Their chemical composition and antioxidant and antimicrobial activities. J. Med. Food 2010, 13, 1005-1012.

12. Amakuraa, Y.; Uminoa, Y.; Tsujia, S.; Itob, H.; Hatanob, T.; Yoshidab, T.; Tonogaia, Y. Constituents and their antioxidative effects in Eucalyptus leaf extract used as a natural food additive. Food Chem. 2002, 77, 47-56.

13. Li, H.; Madden, J.L.; Pottis, B.M. Variation in leaf waxes of the Tasmanian Eucalyptus Species-I Subgenus Symphomyrtus. Biochem. Syst. Ecol. 1997, 25, 631-657.

14. Rahman, A.; Talukder, F.A. Bioefficacy of some plant derivatives that protect grain against the pulse beetle, Callosobruchus maculatus. J. Insect Sci. 2006, 6, 1-10.

15. Hasegawa, T.; Takano, F.; Takata, T.; Niiyama, M.; Oyha, T. Bioactive monopterpene glycosides conjugated with gallic acid from the leaves of Eucalyptus globules. Phytochemistry 2008, 69, 747-753.

16. Ennajar, M.; Bouajila, J.; Lebrihi, A.; Mathieu, F.; Abderraba, M.; Raies, A.; Romdhane, M. Chemical composition and antimicrobial and antioxidant activities of essential oils and various extracts of Juniperus phoenicea L. (Cupressacees). J. Food Sci. 2009, 74, 364-371.

17. Chapuis-Lardy, L.; Contour-Ansel, D.; Bernhard-Reversat, F. High performance liquid chromatography of water, soluble phenolics in leaf litter of three Eucalyptus Hybrids (Congo). Plant Sci. 2002, 163, 217-222.

18. Bendaoud, H.; Bouajila, J.; Rhouma, A.; Savagna, A.; Romdhane, M. GC/MS analysis and antimicrobial and antioxidant activities of essential oil of Eucalyptus radiate. J. Sci. Food Agric. 2009, 89, 1292-1297. 
19. Naceur Ben Marzoug, H.; Romdhane, M.; Lebrihi, A.; Mathieu, F.; Couderc, F.; Abderraba, M.; Khouja, M.L.; Bouajila, J. Eucalyptus oleosa essential oils: Chemical composition and antimicrobial and antioxidant activities of the oils from different plant parts (stems, leaves, flowers and fruits). Molecules 2011, 16, 1695-1709.

20. Singab, A.N.; Ayoub, N.; Al Sayed, E.; Martiskainen, O.; Sinkkonen, J.; Pihlaja, K. Phenolic constituents of Eucalyptus camaldulensis Dehnh, with potential antioxidant and cytotoxic activities. Rec. Nat. Prod. 2011, 5, 271-280.

21. Mulyaningsih, S.; Sporer, F.; Zimmermann, S.; Reichling, J.; Wink, M. Synergistic properties of the terpenoids aromadendrene and 1-8cineole from the essential oil of Eucalyptus globules against antibiotic susceptible and antibiotic resistant pathogens. Phytomedecine 2010, 17, 1061-1066.

22. Damjanovic-Vratnica, B.; Dakov, T.; Sukovic, D.; Damjanovic, J. Antimicrobial effect of essential oil isolated from Eucalyptus globules Labill from Montenegro. Czech J. Food Sci. 2011, 29, 277-284.

23. Rosato, A.; Vitali, C.; de Laurentis, N.; Armenise, D.; Milillo, M. Antibacterial effect of some essential oils administered alone or in combination with Norfloxacin. Phytomedicine 2007, 14, 727-732.

24. Sonboli, A.; Babakhani, B.; Mehrabian, A.R. Antimicrobial activity of six constituents of essential oil from Salvia. Z. Naturforsch. C 2006, 61, 160-164.

25. Bakkali, F.; Averbeck, S.; Averbeck, D.; Idaomar, M. Biological effects of essential oils-A review. Food Chem. Toxicol. 2008, 46, 446-475.

26. Juven, B.J.; Kanner, J.; Schved, F.; Weisslowicz, H. Factors that interact with the antibacterial action of thyme essential oil and its active constituents. J. Appl. Bacteriol. 1994, 76, 626-631.

27. Ultee, A.; Slump, R.A.; Steging, G.; Smid, E.J. Antimicrobial activity of carvacrol toward Bacillus cereus on rice. J. Food Protec. 2000, 63, 620-624.

28. Sikkema, J.; de Bont, J.A.M.; Poolman, B. Interactions of cyclic hydrocarbons with biological membranes. J. Biolog. Chem. 1994, 269, 8022-8028.

29. Burt, S. Essential oils: Their antibacterial properties and potential applications in foodsA review. Int. J. Food Microbiol. 2004, 94, 223-253.

30. Blois, M.S. Antioxidant determinations by the use of a stable free radical. Nature 1958, 181, 1199-1200.

31. Folin, O.; Ciocalteu, V. On tyrosine and tryptophane determination in proteins. J. Biol. Chem. 1927, 27, 627-650.

32. Broadhurst, R.B.; Jones, W.T. Analysis of condensed tannins using acidified vanillin. J. Sci. Food Agric. 1978, 28, 788-794.

33. Naczk, M.; Zadernowski, R.; Shahidi, F. Protein precipitating capacity of condensed tanins of beach pea, canola hulls, evening primrose and faba bean. J. Agric. Food Chem. 2001, 73, 467-471.

34. Arvouet-Grand, A.; Vennat, B.; Pourrat, A.; Legret, P. Standardisation d'un extrait de propolis et identification des principaux constituants. J. Pharm. Belg. 1994, 49, 462-468.

35. Cheng, G.W.; Breen, P. Activity of phenylalanine ammonialyase (PAL) and concentrations of anthocyanins and phenolics in developing strawberry fruit. J. Am. Soc. Hort. Sci. 1991, 117, 946-950. 
36. Methods for Determining Bactericidal Activity of antimIcrobial Agents: Approved Guideline; NCCLS: Wayne, PA, USA; 1999.

37. Moreira, M.R.; Ponce, A.G.; Del Valle, C.E.; Roura, S.I. Inhibitory parameters of essential oils to reduce a food borne pathogen. LWT Food Sci. Technol. 2005, 38, 565-570.

38. Djenane, D.; Yangüela, J.; Amrouche, T.; Boubrit, S.; Boussad, N.; Roncalés, P. Chemical composition and antimicrobial effects of essential oils of Eucalyptus globulus, Myrtus communis and Satureja hortensis against Escherichia coli O157:H7 and Staphylococcus aureus in minced beef. Food Sci. Technol. Int. 2011, 17, 505-515.

Sample Availability: Samples of the compounds are available from the authors.

(C) 2012 by the authors; licensee MDPI, Basel, Switzerland. This article is an open access article distributed under the terms and conditions of the Creative Commons Attribution license (http://creativecommons.org/licenses/by/3.0/). 